\title{
DETERMINANTS OF INCREASING EU FUNDS ABSORPTION CAPACITY IN ROMANIA
}

\author{
PhD George Georgescu, Senior Researcher, Institute of National Economy
}

\begin{abstract}
The study found that, during the early post-accession years, Romania failed to attract European funds, at least to the same extent to the national contribution at the community budget, registering a net expenditure as an EU member. The determinants of increasing EU funds absorption rate are related, among other, to the availability of internal resources for projects cofinancing, adequate administrative capacity at central and local levels, appropriate interinstitutional coordination and public-private partnerships, high skills and motivation of human resources working in operational programs Management Authorities and intermediary bodies. Activating these determinants could be an opportunity for sustaining economic growth of Romania and recovering the development gap, which is supposed to alleviate also the adverse effects of international financial crisis on EU countries.
\end{abstract}

Keywords: economic development, EU integration, structural funds, determinants of absorption capacity, absorption rate, operational programs.

JEL Codes: F15, F36, F43, O19.

\section{Issues of structural funds in European Union}

The aim of cohesion policy, implicitly of structural funds implementation, lies in the transformation and upgrading of the economy of regions and EU countries lagging behind in order to their preparation for the competition into the single market and, respectively, into Euro Area. The policy of economic and social cohesion of the EU has a budget of EUR 308 billion (about 35 percent of the total EU budget) for the programming period 2007-2013, with 3 major objectives: convergence, regional competitiveness and employment and European territorial cooperation. The programming budget is supported by structural instruments (European Regional Development Fund, European Social Fund and Cohesion Fund) and two complementary actions (European Fund for Agriculture and Rural Development and the European Fisheries Fund). Programming and implementation of structural funds is done through the Operational Program (OP), documents prepared by Member States and adopted by the European Commission as part of the National Strategic Reference Framework arising out of the National Development Plan.

It is worth mentioning that financial resources allocated to support cohesion policy for 20072013 have been established, after tough negotiations, in a maximum amount of 0.45 percent of GDP achieved in the EU. In this context, Spain, Portugal, Greece, and many of the new entrants have requested an increase in spending over this ceiling, considered insufficient in relation to the financing needs of achieving the objectives of cohesion policy, but have encountered resistance of net contributor countries (Germany, United Kingdom, Sweden, Austria, Netherlands). Also, the allocation methodology, introduced the concept of absorption capacity, which restricts the transfer of EU funds to a maximum of 4 percent of the respective country GDP. A collateral effect of establishing in this way the absorption capacity was emphasized by the low intensity of aid per capita for the poorest countries, contrary to the philosophy allocation methodology, which implies supporting them with priority. In compensation, at least in part, to facilitate the absorption of funds by the new member countries, the maximum rate of co-financing from EU structural funds 
increased from 80 percent to 85 percent and the rule of financing " $n+2$ " became " $n+3$ " from 2007 to 2010 , being relaxed also certain eligibility criteria.

It is obvious that, under the circumstances of budget constraints, which will probably increase during the period 2009-2013 as a result of the effects of international financial crisis, growing selectivity in the allocation of resources, however limited, both on the formation and utilization side, could endanger the achievement of the objectives of economic and social cohesion, potentially affecting also Romania. Concerning the new Member States, during the transition to a market economy in the 1990s, which left many unresolved institutional and administrativeterritorial issues, it should be noted that only EU accession has brought regional policy on their priorities agenda.

The debate "complementarity or conflict" in EU post-enlargement era gave birth to a new paradigm: the national regional policy. Compared to the classical meaning of the regional policy concept (based on theories of industrial location, with key factors as regional attributes, production costs, availability of labor, etc.), the actual concept is based on modern theories of knowledge at the regional level, with other key factors (regional capabilities, innovative environment, clusters, networks, etc.), this new approach influencing also the allocation of structural funds. More emphasis on regional competitiveness (rather than on regional balance) and on efficiency increase (rather than on productivity improvements), shall be recorded by mutations from individual spatial targets to the regional objectives, and to coordinate policies at the national and regional levels, between center and territory as well (Bachtler J., Wishlade F., D. Yuill, 2003).

It should be noted that in the context of enlarged EU, which significantly increases the territorial development gap - implicitly the number and needs of structural funds beneficiaries - the reduction of aid intensity will indeed make arguably any statement regarding its real contribution to the achievement of cohesion objective, not even mentioning the methodological difficulties for the assessment of the effects of projects financed by the EU. We point out that, at the end of the programming period 2000-2006, there was a certain reduction of gap in respect of GDP per capita between countries, but also growing disparities within member countries and between regions, the cohesion policy and structural funds failing the elimination of unbalanced regional development. On the other hand, the EU Treaty signed in Lisbon in December 2007 refers only to two aspects of cohesion (economic, seen as reducing disparities measured by GDP at the regional level, and social, seen as reducing inequalities between individuals in regions) focusing, as the most important targets, on education and employment. It is obvious that the process of economic and social cohesion does not evolve in a similar manner to all the territories and to all individuals, spatial development process having a high degree of concentration, while population and activities remain polarized in certain areas.

Taking into consideration that structural interventions are generally on short and medium term, while on long-term the market itself should ensure an increase in the general welfare, implicitly a reduction of disparities, including territorial, the real challenge of the EU, in our view, is to prove the resilience of European architecture, which is facing global economic competition, deep crisis on international financial markets, threats of recession, uncertainties on the energy and raw materials world markets.

\section{Determinants of EU funds absorption capacity}

An introspection of the literature regarding the absorption of EU structural funds reveals a lack of adequate conceptual framework while the topic of better ways to manage these funds is less addressed. As the explanation could not be related to the lack of interest in studying such a problem, the reasons are essentially linked to its relative novelty, to the difficulties in assessing the impact of structural funds on the convergence of EU countries in the long term, to construction of appropriate indicators, including for the measurement of the absorption capacity. Most often, the absorption 
capacity is understood as the extent to which a Member State is able to spend the financial resources allocated from the Structural Funds, in an effective and efficient manner, having three connotations:

- macroeconomic absorption capacity, defined and measured in terms of GDP (limited, as mentioned, to 4 percent);

- financial absorption capacity, defined as the ability to co-finance the programs and projects supported by the EU, to plan and guarantee these national contributions in multi-annual budgets, and to collect contributions from the partners involved in various programs and projects;

- administrative capacity, defined as the ability and qualifications of central and local authorities to prepare programs and appropriate and timely projects, to decide on them, to ensure coordination of partners involved, to comply with administrative and reporting requirements, to funding and monitoring the implementation of programs and projects, to avoid irregularities.

The performance, respectively how the structural funds were used effectively and efficiently, is considered an output variable, being possible to be evaluated ex-post, at the end of the programming period. For new entry countries, a theoretical pre-assessment of performance is possible, depending on the results obtained during the use of the pre-accession funds. To create the prerequisites of an effective and efficient management of structural funds, and the performance thereof, a great attention should be paid to their programming (structure, human resources, systems and tools) as an input variable, which depends on requirements arising from EU rules on the matter (Boeckhout S., L. Boot, etc., 2002).

Taking into account the absorption capacity definition above mentioned it is believed that it is influenced mainly by the administrative-managerial and co-financing capabilities. The relationship between the absorption capacity of structural funds and the regional economic situation is a paradoxical one, the practice demonstrating that the most disadvantaged regions are experiencing also the greatest difficulties in the absorption of these funds. At the same time, they are the regions that need, theoretically and practically, the largest financial support for restructuring the economy. The main explanation for this paradox lies in two factors: on the one hand, the difficulties of regional authorities due to lack of experience and qualifications, which are added to those arising from bureaucratic procedures and slowness of EU decision-making process under the circumstances where sequential procedures for programming at the central level and especially regional are not clear.

There is a consensus upon the fact that the problems of absorption capacity depend heavily on institutional factors, both of EU and national structures. At the EU level, institutional factors are related primarily to the European Commission: the transparency of funds allocating process, the consistency of using various funds and other factors such as bureaucratic administration, whose organizational capacity can be affected by lack of vertical communication and of horizontal coordination. At the national level, institutional factors are related to the real structure of the economy, the administrative capacity, the political system (federal versus central), and the economic policies. Therefore, even under the conditions of a similar funds transfers (as absolute and / or relative size), it is expected that issues of absorption differ from country to country.

Other important determinants of the absorption capacity refer to programming and institutional building and to administrative capacity development during the pre-accession period. In accordance with the Commission's recommendations and best practices of EU countries, a golden rule came obvious, under which, less the number of institutions involved in different levels of management and programs (sectoral and regional) in new member countries, greater the possibility of higher rates of structural funds absorption (A. Horvath, 2004).

It was found that the Regional Development Agencies have a particular role in the implementation of structural funds, especially at project level and the quality of their work positively affect the absorption rate. On the other hand, the Regional Development Agencies are much differing in different states. In countries such as Ireland, Portugal and Greece - characterized 
by strong central administration - with key role in the decision on allocation and monitoring of structural funds - territorial agencies play a minor role. In Sweden, France and the UK - with a less degree of concentration of the administrative system - the main powers of implementation of structural funds back on regional offices of national administration. In countries such as Germany, Austria and Belgium - federal states, with a decentralized administrative system - the implementation of structural funds falls wholly or partly, on regional authorities. Such a system exists also in non-federal countries like Denmark, Finland and the Netherlands, which have a higher degree of regional autonomy.

If structural funds have not severely using constraints, it is believed that their impact on capital accumulation and economic growth may be lower than expected. In the European context, decisions may be affected also by the fact that the beneficiary countries, knowing in advance what are the funds received from the EU budget for the next six years, prefer to delay the structural adjustments; for example, the eligibility criteria of the Objective 1 (regions with a GDP / capita below $75 \%$ of the EU average) may reduce the motivation to accelerate economic growth, in order to benefit from structural funds for a longer period of time. Another example of the practice of some countries is that governments are neglecting the maintenance of existing capital stock in order to meet the requirements of co-financing Operational Programs projects, which reduces the potential growth, missing also the fact that, once completed, projects requirements continued allocations from the public funding.

\section{The EU funds absorption rate in Romania during the first years post-accession}

We are pointing out that the structural funds (including those of cohesion) allocated to Romania from the EU budget for the programming period 2007-2013, are EUR 19.2 billion, plus national co-financing (state budget, local budgets and private sector), of another around EUR 9 billion. Structural funds are implemented through a 5 Sector Operational Programs (SOP respectively, for Transports EUR 4.5 billion, for Development of human resources EUR 3.4 billion, for Increasing economic competitiveness EUR 2.5 billion, for Development of administrative capacity EUR 208 million; for Environment EUR 4.5 billion), a program of regional development (ROP, respectively EUR 3.7 billion) and a technical assistance program (EUR 170 million).

Out of the total structural and cohesion funds allocated to Romania, our country counted for EUR 1.28 billion in 2007. According to a study published by the National Bank in March 2008, with only EUR 0.42 billion drawn from the EU budget, the absorption rate of these funds stood only for 32.7 percent. As noted in NBR study, the primary cause of the low absorption rate of structural funds is linked to delays in programs elaboration at the national level, but also in decisions concerning the budget at the EU level, which made the 7 operational programs to be sent to Brussels only in June 2007, so at 6 months after the entry of Romania into the European Union. Under the circumstances of no available data concerning the concrete use of the EUR 420 million drawn from the structural and cohesion funds, respectively on what specific programs, axes or areas of intervention the money has been spent, there are big doubts about the real rate of absorption. More than that, from the public information does not result the start of the funding (with disbursement from the EU) of any project within the operational programs.

On the other hand, if along with the structural and cohesion funds are taken into account the funds for agriculture and rural development allocated to Romania in 2007, amounting to EUR 0.76 billion, as seen in Table 1, the absorption rate of total European funds stood only for 21.7 percent, compared with about 42 percent carried out by Hungary, Poland, Slovakia or the Czech Republic. Furthermore, if for these countries, which joined the EU in 2004, there is a real absorption rate, in the case of Romania, to be relevant, it needs to be calculated in 2010, when, according to the "n +3 " rule, would know exactly the funds spent and reimbursed from the EU budget during 2007-2009. It is worth mentioning that the procedures of structural funds accession from the EU budget is very 
rigid, according to the " $\mathrm{n}+3$ " rule, the projects requiring to be contracted, completed, implemented and disbursed within a maximum of 3 years after the funding approval.

Regardless the relativity of data, it is obvious that in 2007, Romania has recorded a negative net position towards the EU budget (representing 0.36 percent of GDP), being in the paradoxical situation of net contributor, despite the fact that among the EU-27 member countries stand for the penultimate position in terms of economic development level (as GDP per capita), in theory benefiting from greater funds to support the process of convergence and gap recovery.

A significant improvement of this situation is not be expected in 2008 either: according to our estimation, even the government target concerning the absorption rate of EU funds would be around only 40 percent (EUR 2.9 billion total EU funds allocated over EUR 1.2 billion likely to be absorbed compared with EUR 1.4 billion contribution to the EU budget), predictable not to be achieved, Romania will stand for the second year, on the position of net contributor.

In September 2008, the European Commissioner for Regional Development stated that the payment of structural funds for Romania may not start until the government sends to Brussels a report of conformity regarding the management system of these funds, certificated by the audit national authorities. In the first 8 months of 2008, Romania has been granted in advance payments of around EUR 1 billion, but to receive the next installments and begin effectively the disbursements, audit reports on the implementation of operational programs proposed by the Romanian government must be approved by the EU. On the other hand, from the statements of Ministry of Finance officials, is not resulting that would have been made payments for any project from the structural funds received in advance, at least by September 2008.

We think that debating the issue of European funds absorption in Romania is somehow confusing, the main reason being linked to the lack of transparency at the central government, particularly at the level of operational programs management (the line ministries), less disposed to admit the existing vulnerabilities in this regard and to identify possible remedies. Instead of an analytical image, it presents an incomplete picture of European funds absorption, pointing out only positive aspects, which also makes a purely scientific approach difficult.

It is important to note that during the phase of projects implementation, the absorption of structural funds may be subject to being influenced by the vulnerabilities arising from the macroeconomic framework of Romania, both internally and externally. Given the possible effects of international financial crisis on economic growth, a possible abrupt adjustment of exchange rates and maintaining a high rate of inflation during the period 2009-2012 are expected to create pressure on the contracts deployment (concluded in local currency), and the cost of construction works. It should also be taken into account developments on the labor market in the construction sector which already faces a crisis of labor, affecting the wages of workers and technicians in the sector and also the deadlines of constructions.

A major vulnerability that could affect Romania's absorption rate of European funds is the rigidity of the banking system as regards loans for co-financing of projects. In the context of strengthening the lending conditions imposed by the NBR, including mitigating the effects of international financial crisis, interests and commissions charged by commercial banks rose, and applicants are asked to deposit a percentage of the amount financed (up to 20-25 percent), as cash collateral, which remains locked until the loan has the bank approval, which can mean a delay of several months.

\section{Case study: the Regional Operational Program}

At the end of June 2008, from the information published by the Ministry of Economy and Finance we think that, within the seven existing Operational Programs, out of the total of 1297 projects submitted, a number of 281 projects were approved, with a value of around EUR 2.5 billion, of which EUR 1.8 billion accounting for EU funds. Out of 281 approved projects were 
concluded only 23 financing contracts with the beneficiaries, with a total value of around EUR 204 million, of which EU funds accounting for EUR 180 million. So, indirectly, after a year and a half of Romania's accession to the EU it is not confirmed that would have been disbursed (effectively absorbed) even one EUR from the structural and cohesion funds, for a specific project.

Among all Operational Programs, (ROP) is considered as best articulated and advanced. However, it is worth mentioning that the so-called advance of the ROP, at least concerning the submitted projects, is not due to any merit of the management authorities, but rather to the fact that a number of projects from the reserve of pre-accession program "PHARE Economic and Social Cohesion 2003, respectively 2004-2006", adapted to the requirements of new Applicant Guides, under the technical assistance of the former Ministry of European Integration, were transferred to ROP.

The Regional Operational Program is structured on five Priority Axes and fifteen major areas of intervention, respectively financing lines (making abstraction of Priority Axis 6, respectively Technical Assistance), having a budget of EUR 4.5 billion over the programming period 2007 - 2013 (of which EUR 3.7 billion contribution of EU). This program, having the Ministry of Development, Public Works and Housing (MDPWH) as Management Authority and eight regional development agencies as intermediary bodies, was approved and became operational on July 12, 2007.

By the end of September 2008, the Management Authority approved payments of EUR 2.2 million, out of which the Certification Authority certificated payments of only EUR 0.7 million, i.e. absorption rate near zero. In the absence of data on funds effectively disbursed from structural EU funds, the main criteria for assessing the progress of any operational program implementation, including ROP, remains the number of projects submitted. It should be noted that, from the submission of a project to its approval, signing of financing contracts and starting the disburse of the first expenditures from the EU (effective absorption of structural funds) a long road has to be passed by the process of assessment (compliance, eligibility, technical and financial), including strategic assessment, which may take more than a year.

It is noteworthy that, until the end of September 2008, in the major areas of intervention of ROP 1112 projects had been submitted, of which 733 projects were in various stages of the assessment, selection and contracting, cumulating a total value of more than EUR 2 billion. The largest part of its focus on the Priority Axis 2 (Improving the regional and local transport infrastructure) respectively EUR 1507 million, almost double compared with EUR 876.7 million available for this axis for the entire programming period in $2007-2013$. This is why the submission of further projects for this axis has been suspended since October 16, 2008, yet for two regions.

A number of 66 projects were in various stages of pre-contracting, 8 being under internal assessing of Management Authority, 3 in the stage of pre-contracting visit, and 55 in the stage of filing the technical project. At the end of September 2008, on all axes (except Priority Axis 6 Technical Assistance), only 9 contracts were concluded, all belonging to the Priority Axis 2, having a value of 535.1 million lei (EUR 163.2 million), of which 435.6 million lei (EUR 132.8 million) grants from EU structural funds, which would represent almost $90 \%$ of the amount scheduled for this axis through the Framework Document of ROP Implementation for the years 2007 and 2008.

As follows, ROP finds itself in a paradoxical situation in which, although virtually no disburse has begun for any project, the submission of others has been canceled, which means not only a blockage of funds (becoming evident also their under-sizing), but in fact, proving the inability of the administrative management to keep pace with the needs of developing the regional transport infrastructure, and the absorption of available structural funds, at least so far. Under these circumstances, MDPWH has announced that applications for funding for eligible projects whose value exceeds the regional financial allocation will be included in a list of reserves, and that the assessment process for them can be unlocked only if - and when - additional amounts are supplemented within the area of intervention for the region in question. 


\section{Conclusions}

We appreciate that Romania's inability to use EU funds is endemic, even if it can be explained by the action of various factors, including bottlenecks in public administration under the circumstances of general and local elections in 2008. The fact that our country fails to attract European funds in the early years post-accession, at least to the same extent to the national contribution at the community budget, registering a net expenditure as a EU member is a situation not only paradoxical, but with dramatic effects on the horizon of development gap recovery and of real convergence with EU countries.

In conclusion, we appreciate that, to increase the absorption capacity of European funds, the Romanian authorities should activate a number of specific factors, including:

- Strengthening administrative capacity, including on the account of preparing qualified personnel and avoiding fluctuation of employees in the system, both at the level of line ministries and of regional development agencies;

- Greater transparency by providing exhaustive information and elimination of excessive bureaucracy (which is generating corruption) from the system of financing projects approval, but also by providing comprehensive information of public interest;

- Stabilization of the rules governing the access to structural funds, particularly the requirements of the Applicant Guidelines, avoiding further corrections that delay the approval process of eligible projects;

- Completion of audit reports on the implementation of Operational Programs by the Management Authorities, so that they can be approved by the EU by the end of 2008 , conditionality for starting the reimbursements;

- The regulation of contractual relations between the different institutions at the central and local levels, between them and consulting firms, respectively the project beneficiaries, so that deficiencies in contractual matters can no longer affect the deadlines for approving the funding, implicitly the rate of structural funds absorption;

- Establish performance criteria for consultancy firms agreed by the central Management Authority for the preparation of feasibility studies (including technical, if necessary) with severe penalties in cases of noncompliance with commitments assumed (quality and deadlines);

- Reducing the duration of the evaluation, selection and contracting procedures by increasing the quality, both for funding applications (providing all documentation required), and for Management Authorities and intermediary bodies.

- The inclusion both in the central and local budgets of the amounts planned by the central / local government for co-financing of projects from the structural funds, complying with the conditions imposed by the schemes of state aid;

- Analysis at the level of the Ministry of Economy and Finance of all applications for eligible projects funding, which, due to the fact that it exceeded the regional financial allocation, have been included in the reserves list, trying to find other sources of financing the projects of high national or regional interest.

\section{References:}

1. Bachtler J., Wishlade F., Yuill D., Regional Policies after 2006: Complementarity or Conflict?, European Policy Research Paper no 51/2003.

2. Bachtler J., Mendez C., Who Governs EU Cohesion Policy? Deconstructing the Reforms of the Structural Funds, University of Strathclyde, JCMS Volume 45, No 3/2007.

3. Boeckhout S., Boot L. et al, Key indicators for Candidate Countries to Effectively Manage the Structural Funds, Final Report, NEI, Rotterdam, February, 2002. 
4. Boot L., de Vet J-M., Feekes F., Absorption capacity for Structural Funds in the regions of Slovenia, NEI, Rotterdam, August, 2002.

5. Horvat A., Absorption problems in the EU Structural Funds, NARG, Ljubljana, 2004.

6. Horvat A., Financial Absorption Rate in EU Objective 1 1994-99 and Some Lessons for the New Member States in 2004-2006, WIFO, Working Papers 259, September 2005

7. Isărescu M., Atragerea fondurilor europene în România, Forumul Național pentru Dezvoltare Durabilă şi Protecția Mediului, Bucureşti, 14 March 2008.

8. Kalman J., Possible Structural Funds Absorption Problems, Cambridge University Press, 2006.

9. Polverari L., McMaster I., Territorial cohesion and new cohesion policy: challenges for old and new Member states, 1st ESPON Scientific Conference, Malmo, 2006.

10. *** A Study on the Efficiency of the Implementation Methods for Structural Funds, Final Report, ÖIR, Vienna, December, 2003.

1. $11 * * *$ Cadrul Strategic Naţional de Referință 2007-2013, Guvernul României.

11. *** Europeanul no 4, 1 - 21 October 2008.

12. *** General provisions on the European Regional Development Fund, the European Social Fund and the Cohesion Fund, Council Regulation (EC) No 1083/2006, Brussels, July, 2006.

13. *** Impactul fondurilor structurale în România. Evaluare cu ajutorul modelului HEROM (CEROPE Phare Program Ro 2003/005-551.02.03), CNP, 2007. 